Review

\title{
Chronobiology of Melatonin beyond the Feedback to the Suprachiasmatic Nucleus-Consequences to Melatonin Dysfunction
}

\section{Rüdiger Hardeland}

Johann Friedrich Blumenbach Institute of Zoology and Anthropology, University of Göttingen, Berliner Str. 28, Göttingen D-37073, Germany; E-Mail: rhardel@gwdg.de; Tel.: +49-551-395414

Received: 17 February 2013; in revised form: 1 March 2013 / Accepted: 4 March 2013 /

Published: 12 March 2013

\begin{abstract}
The mammalian circadian system is composed of numerous oscillators, which gradually differ with regard to their dependence on the pacemaker, the suprachiasmatic nucleus (SCN). Actions of melatonin on extra-SCN oscillators represent an emerging field. Melatonin receptors are widely expressed in numerous peripheral and central nervous tissues. Therefore, the circadian rhythm of circulating, pineal-derived melatonin can have profound consequences for the temporal organization of almost all organs, without necessarily involving the melatonin feedback to the suprachiasmatic nucleus. Experiments with melatonin-deficient mouse strains, pinealectomized animals and melatonin receptor knockouts, as well as phase-shifting experiments with explants, reveal a chronobiological role of melatonin in various tissues. In addition to directly steering melatonin-regulated gene expression, the pineal hormone is required for the rhythmic expression of circadian oscillator genes in peripheral organs and to enhance the coupling of parallel oscillators within the same tissue. It exerts additional effects by modulating the secretion of other hormones. The importance of melatonin for numerous organs is underlined by the association of various diseases with gene polymorphisms concerning melatonin receptors and the melatonin biosynthetic pathway. The possibilities and limits of melatonergic treatment are discussed with regard to reductions of melatonin during aging and in various diseases.
\end{abstract}

Keywords: age-related diseases; aging; circadian; melatonergic agonists; melatonin; $\mathrm{MT}_{1}$; $\mathrm{MT}_{2}$; peripheral oscillators; polymorphisms 


\section{Introduction}

Melatonin is primarily known as the hormone of the pineal gland, although its synthesis in additional extrapineal tissues and cells is documented by a large body of evidence [1]. In mammals, extrapineal melatonin is either poorly released to the circulation or only for short periods of time. Therefore, the circulating hormone mainly reflects its secretion by the pineal. Its chronobiological effects are, in mammals, mainly exerted by the pineal-derived fraction. Moreover, melatonin is not only released to the blood, but also, via the pineal recess, in relatively high initial concentrations, to the CSF $[2,3]$. Whether or to what extent these amounts secreted to the CSF contribute to circadian regulation is widely unknown.

In relation to the circadian system, melatonin is both an output and an input factor [4]. In brief, the mammalian pineal gland is controlled by the circadian pacemaker, the pair of suprachiasmatic nuclei $(\mathrm{SCN})$, which receive photic information from the retina, in particular, from the melanopsin-containing retinal ganglion cells. The SCN stimulates melatonin biosynthesis only during scotophase, whereas light is inhibitory to this process. The information "darkness" is transmitted to the pineal via a neuronal pathway, which includes the paraventricular nucleus, an intermediolateral cell column of the upper thoracic cord, and a preganglionic sympathetic connection to the superior cervical ganglion, whose postganglionic fibers innervate the pineal [5]. Melatonin formation is stimulated (i) by $\beta_{1}$-adrenergic activation of adenylyl cyclase and, thereby, protein kinase $A$, and (ii) $\alpha_{1 \mathrm{~B}}$-adrenergic activation of phospholipase $\mathrm{C} \beta$ that leads to rises in $\mathrm{Ca}^{2+}$, protein kinase $\mathrm{C}$ and $\mathrm{CaM}$ kinases. With regard to the contribution of enhanced gene expression of the biosynthetic enzymes and their post-translational regulation, the mechanisms differ between mammalian taxa. Moreover, these processes are modulated by several peptidergic and glutamatergic mechanisms (summarized in [6]).

The nocturnal stimulation of melatonin biosynthesis leads to a high-amplitude circadian rhythm in the concentration of the circulating hormone, which further transmits the information "darkness" to virtually all, at least numerous, tissues $[7,8]$. The rhythmic input of enhanced melatonin to the various organs and CNS areas is, according to current evidence, not identical in mechanistic terms and seems to concern different levels of action. In some cell types, melatonin presumably only up- or downregulates certain genes, i.e., exerts direct effects without necessarily affecting circadian oscillators. However, in the SCN, it modulates the oscillations in the pacemaker. This may affect both the amplitude and the phase of the primary oscillations. Changes in phase are known under the term of "chronobiotic" effects. Like other synchronizing signals, phase shifting by melatonin occurs according to a phase response curve, which has also been studied in humans [9,10]. In this role, melatonin acts as a feedback signal that contributes to the adjustment of the pacemaker to the external cycle and, presumably, to the maintenance of high-amplitude oscillations.

Contrary to earlier concepts, cellular circadian oscillations are not restricted, in vertebrates, to a pacemaker. As will be outlined next, oscillators based on same or similar cellular machineries as in the SCN are acting in numerous tissues, including various CNS areas as well as peripheral organs. The dependence of these oscillations on SCN-derived signals varies considerably among oscillators and some of them seem to be relatively autonomous [11,12]. With regard to the presence of melatonin receptors in remarkably many cell types [1], the question arises as to whether and, if so, to what extent the oscillators outside the SCN are influenced by the pineal hormone. 


\section{The Circadian Multioscillator System}

The multiplicity of circadian oscillators in a mammalian body is remarkable. This diversity comprises different levels [12]: (i) oscillators are found in numerous organs, tissues, tissue explants and isolated cells; (ii) within an organ or CNS area, subpopulations of cells may constitute several oscillatory subsets, which can differ in their phase response to various time cues, a phenomenon that has even been observed within the SCN [12-14]; (iii) within a single organ and, perhaps, even a cell, parallel oscillators can exist, which operate on the alternate use of homologs or paralogs of core oscillator proteins and their respective genes. For example, the simultaneous expression of PER1 and PER2, frequently also of PER3, as well as CRY1 and CRY2, is a normal experience in the majority of tissues. The core oscillator protein CLOCK is sometimes replaced by its paralog, NPAS2. The consequence, namely multiplicity of oscillatory and regulatory properties, is even surpassed by the fact that the core oscillators are operating within a host of other regulatory proteins that interact with them and are differently expressed in the various cell types [15-17]. Several of them act as both output and back-feeding input factors of the core oscillator, others transmit external and intracellular information, e.g., concerning food or cellular energy status. Moreover, core oscillator proteins are thought to directly interact with other transcription factors to form a variable number of functionally diverse multi-protein complexes [17].

With regard to the fact that circadian oscillators are primarily cellular machineries, all nucleate cells may, in principle, be assumed to be capable of generating circadian oscillations. However, evidence exists for a substantial diversity concerning their autonomy. While some peripheral oscillators have been shown to possess a high degree of autonomy and to be relatively independent of the SCN and poorly or moderately influenced by the light-dark cycle [11,18,19], others are less autonomous [12] and may be regarded as slave oscillators of the SCN. In various cases, it has been observed that peripheral oscillations fade out under constant experimental conditions [12], in contrast to the long-lasting self-sustained oscillations of the SCN.

A full record of oscillators outside the SCN, which have been convincingly demonstrated or likely exist in the central nervous system and in peripheral organs, would exceed the scope of this article. The focus will rather be laid on those oscillators which have been shown to be modulated by melatonin or seem to be influenced indirectly by other actions of the methoxyindole. It should also be noted that the evidence for peripheral oscillators is not generally based in every case on cycles of all core oscillator proteins or their respective mRNAs, but is sometimes limited to rhythms in a few of them, such as PER1, PER2 and/or BMAL1. Central nervous oscillators outside the SCN have been demonstrated in the retina [20-27] and seem to exist, e.g., in the arcuate nucleus [28,29], the lateral hypothalamic area [29], dorsomedial nucleus [28], striatum [30,31], hippocampus [32] and solitary tract caudal brainstem nucleus [33]. Among brain-associated non-neuronal tissues, oscillators in the pars tuberalis (PT) [34-40] and the main part of the anterior pituitary [41,42] have to be mentioned. The PT oscillator should be of particular importance in seasonal breeders, whereas its role in other mammals remains to be clarified. Peripheral oscillators have been detected in adrenal cortex [43-46], pancreatic islets [47-49], exocrine pancreas [48], liver [29,41,50-60], adipose tissue [29,58,61], kidney [50,57], heart [50,52,58,62-65], blood vessels [65], muscle [29], stomach [59], oviduct [66], osteoblasts [67,68] and fibroblasts $[69,70]$. 


\section{Chronobiological Effects of Melatonin outside the SCN}

Without detailed analysis, it is impossible to decide whether melatonin-induced changes in cellular parameters are based on the modulation of circadian oscillators and if so, at which regulatory level. In fact, a full spectrum of different possibilities seem to exist in a mammalian body, from direct effects not involving an oscillator to the modulation of oscillators with different degrees of independence from the SCN (Figure 1). Direct up- or downregulation of an enzyme does not per se require a cellular oscillator, although an overlap with additional effects mediated by a cellular clock cannot be generally excluded. Direct enzyme induction may be the case in glutathione peroxidase (GPx), which is upregulated by melatonin in numerous tissues, in both nocturnally active rodents and diurnally active birds [71,72]. In mammalian and avian brains, this enzyme peaks at night, but deviatant patterns have been described for other tissues [71]. However, GPx expression and activity are also influenced by other parameters, notably by the cellular redox balance, which can temporally differ between tissues. The direct involvement of melatonin is supported by strong reductions in GPx activity in pinealectomized rats [73] and the suppression of the GPx rhythm by light in chicken [74], findings that should not be expected if GPx activity would be primarily driven by a peripheral oscillator. Such a rhythm that is mainly produced by the periodicity of the inducer, melatonin, may secondarily generate other rhythms. This was assumed for the rhythm of glutathione reductase (GRd), which follows with a certain delay that of GPx, and is also abolished by light. GRd is known to be induced by a shift in the GSSG/GSH balance towards the oxidized form, which should occur as a consequence of de novo synthesized GPx. This is consistent with a GRd rhythm with a maximum appearing after that of GPx $[72,74]$. Whether or not these conclusions on direct or secondary inductions by melatonin or melatonin-mediated changes in the redox balance may also apply to the upregulation of several other antioxidant enzymes, remains to be clarified. This would especially concern $\gamma$-glutamylcysteine synthase, glucose-6-phosphate dehydrogenase, $\mathrm{Cu}, \mathrm{Zn}$ - and $\mathrm{Mn}$-superoxide dismutases and hemoperoxidase/catalase (reviewed in [1,75-77]).

Although the body of evidence for a role of melatonin in peripheral oscillators is still limited, several findings speak for such a conclusion. A case of particular importance is that of the oscillator in the adrenal cortex, because of the high-amplitude rhythm of glucocorticoid secretion generated there and the numerous effects of these hormones in other organs, in which they up- or downregulate countless genes. Enzyme induction and deinduction by glucocorticoids is classic biochemical knowledge, but it has been shown that these changes, especially in cyclically expressed genes, also depend in their extent on the circadian phase [78-80]. The importance of the glucocorticoid rhythm in the orchestrated phasing of peripheral oscillators has gained support by several recent studies. These hormones did not only favor the reentrainment of rhythms in various organs, in a tissue-specific manner [81], but also phase-shifted circadian gene expression in liver, kidney and heart, in the absence of corresponding effects in the SCN [82]. In cultured rat-1 fibroblasts, dexamethasone was shown to induce circadian oscillations in the expression of core oscillator and associated proteins [82]. Recently, using a luciferase reporter under control of the Bmall promoter, circadian amplitudes were strongly enhanced and reset by co-culture with adrenal, but not thyroid or lung tissue [83]. Similar results were obtained by dexamethasone treatment of quiescent bone marrow mesenchymal stem cells [84]. On the other hand, glucocorticoids were also reported to interfere with food-induced phase-shifts of the 
peripheral oscillators in liver and kidney [85]. In the mouse lung, Clara cells were shown to possess a glucocorticoid-sensitive oscillator [86]. Collectively, these findings indicate that any alteration in the glucocorticoid rhythm, either caused by melatonin or resulting from its absence, would presumably lead to a plethora of secondary effects in the circadian multioscillator system.

Figure 1. Schematic overview of the influences of melatonin on circadian oscillators of different degrees of independence from the SCN, additional effects by direct control of gene expression and the role of other hormones modulated by melatonin, such as glucocorticoids, insulin and some pituitary hormones.

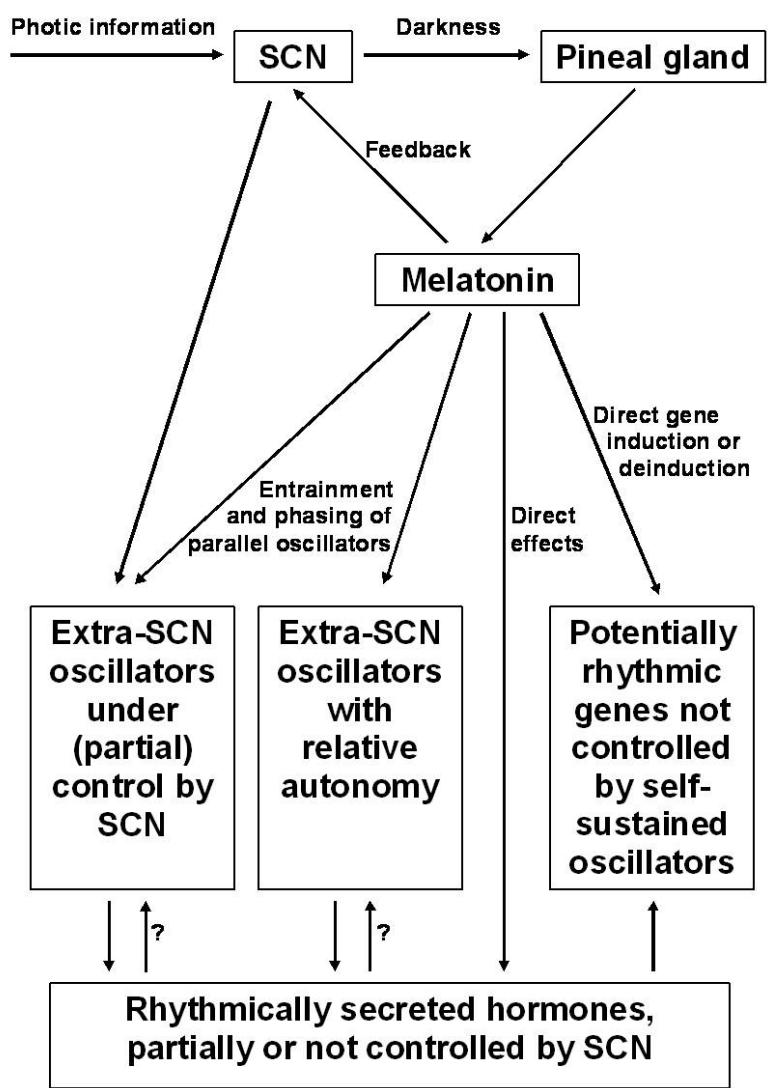

Our understanding of the adrenal cortex oscillator has meanwhile considerably changed. The periodic synthesis and secretion of glucocorticoids is now known not to be just the consequence of the ACTH rhythm [44-46], and melatonin was additionally shown to interfere via the $\mathrm{MT}_{1}$ receptor with the ACTH-induced cortisol release [87]. Although this inhibitory action might indicate, at first glance, a general suppressive role of melatonin in the adrenal, the opposite is true, from a chronobiological point of view. This became evident in a comparison of the melatonin-proficient mouse strain, $\mathrm{C} 3 \mathrm{H}$, with the melatonin-deficient strain, C57BL [43]. In C3H, protein levels of PER1, CRY2 and BMAL1 were shown to oscillate with robust amplitudes, whereas C57BL exhibited only weak fluctuations and reduced expression of these proteins. These findings in the adrenal cortex strongly contrast with others obtained in the adrenal medulla, which is part of the sympathetic system and, thus, under direct neuronal control. In the medulla, the circadian clock was not substantially impaired by melatonin deficiency in C57BL [43]. 
However, neuronal control is not per se an indicator of melatonin independence. In fact, the murine retinal oscillator is strongly reminiscent of that one in the adrenal cortex, as far as the requirement of melatonin is concerned. Again, robust rhythms of PER1 and CRY2 levels were present in C3H mice, whereas C57BL mice did not show significant rhythms in these core oscillator proteins [22]. Comparisons between $\mathrm{C} 3 \mathrm{H}$ and $\mathrm{C} 57 \mathrm{BL}$ mice also revealed that the circadian rhythm of retinal dopamine damped out in DD in the melatonin-deficient strain, but not in $\mathrm{C} 3 \mathrm{H}$, a finding that also indicates a requirement of melatonin for the stable maintenance of peripheral cycling [88]. Daily injections of melatonin restored the retinal dopamine rhythm in C57BL. Similar findings were obtained for a rhythm in dopamine-dependent, PKA- and CAM kinase-mediated phosducin phosphorylation [89], which also damped out in C57BL but not $\mathrm{C} 3 \mathrm{H}$ [26]. However, these results have also to be seen in the context of the intraretinal dopamine/melatonin antagonism [26,90], including the fact that they were obtained in rodents in which melatonin is synthesized in the retina $[20,26]$, whereas this is not or only poorly the case in several other mammalian taxa, especially in primates including humans $[91,92]$. Therefore, it remains to be clarified whether eventually existing very low intraretinal melatonin levels or the circulating pineal-derived melatonin will be as important to a retinal oscillator in primates as in rodents.

Another neuronal oscillator outside the SCN, located in the striatum, was also shown to depend on the melatonin cycle. In mice, the circadian rhythms of Perl mRNA and PER1 protein levels were abrogated by pinealectomy [30]. In cultured murine wild-type striatal neurons, $1 \mathrm{nM}$ melatonin downregulated Clock and Per1 expression, and upregulated that of NPAS2, at the mRNA level, whereas Bmall was weakly affected [31]. These changes were not observed in $M T_{1}$ receptor knockouts.

Another peripheral oscillator that is obviously influenced by melatonin is located in the pancreatic islet, which has also been in cultured explants [49,93]. Apart from increased levels of insulin secretion observed in $M T_{1}$ and $M T_{2}$ receptor knockouts as well as in respective double knockouts, the circadian rhythms of insulin transcripts as well as of circulating insulin were changed with regard to both phase and amplitude in the receptor-deficient animals [93]. Moreover, alterations of phase and amplitude were also described for the rhythms of Perl, RevErba and Dbp expression in both pancreas and liver [93]. The influence of melatonin on other peripheral oscillators awaits further clarification. Studies on double knockouts may be regarded as a first-line approach to study this question.

The skin is another organ in which several cell types exhibit endogenous oscillations of clock gene expression. In the murine skin, such rhythms were detected in keratinocytes and hair follicle cells [94]. At least in mice, these cutaneous oscillators are, however, SCN-dependent and fade out after ablation of the central pacemaker. In humans, rhythmic clock gene expression has been convincingly demonstrated in hair follicle cells [95,96]. At the mRNA level, Per2, Per3, Dbp, Nr1d1 and Nr1d2 oscillated with robust amplitudes, whereas those of Bmall and Npas2 exhibited only weak fluctuations [95]. Whether and to what extent these endogenous rhythms are influenced by melatonin remains to be clarified. If they are, as in mice, generated by a slave oscillator of the SCN, melatonin would be primarily relevant via its effects on the pacemaker. The situation is complicated by the cutaneous synthesis of melatonin and hormones otherwise known from the hypophyseal-pituitary-adrenal axis as well as the expression of melatonin receptors in the skin, mainly $\mathrm{MT}_{1}$ [97-99]. However, the influence of melatonin via cutaneous receptors was assumed to be less dependent on the circulating hormone, but rather on a continuous exposure to skin-derived melatonin [97]. 
Apart from the evidence obtained in melatonin-deficient genotypes, pinealectomized animals and receptor knockouts, as described, melatonin may have an additional effect on peripheral oscillators, although, in this case, its action is not independent of the SCN. This concerns the circadian rhythm of core body temperature, which is believed to be generated at the SCN, but which strongly depends, in humans and presumably other diurnally active mammals, on the feedback by melatonin, which is involved in the nocturnal decrease of this parameter [100-102]. This view is supported by the observation that, in elderly subjects, a deteriorated rhythm of body temperature can be normalized by melatonin [103]. Newly emerging evidence reveals the relevance of the core body temperature to peripheral oscillators. By contrast with the relative resistance of the SCN to entrainment by temperature, the peripheral oscillators are more strongly influenced [104]. Earlier results first demonstrated a support of rhythmic gene expression by low-amplitude temperature cycles in cultured peripheral cells [105], findings that were later extended to synchronization [106]. Actually, the normal physiological temperature cycle is believed to also entrain various autonomous or semiautonomous oscillators in vivo [104,107]. Thus, the hypothermic effect of melatonin may, in diurnally active mammals including humans, contribute to phasing and maintenance of amplitudes of peripheral oscillators.

\section{Melatonin Dysfunction}

Melatonin dysfunction can either result from gene variants or be acquired during life, in the course of aging or as the consequence of a disease. With regard to the remarkable pleiotropy of melatonin, such deviations should cause numerous secondary effects, including chronobiological alterations, and have the potential of pathophysiological relevance.

Gene variants that are statistically associated with pathologies either concern the biosynthetic pathway of melatonin formation or melatonergic signaling. However, in all these cases, it should be kept in mind that these associations only reflect risk factors, which may not necessarily lead to a disease in the absence of other influences, e.g., combination with other risk factors or an unfavorable lifestyle. Among gene variants concerning melatonin biosynthesis, polymorphisms of the arylalkylamine $\mathrm{N}$-acetyltransferase (Aanat) gene were found to be associated with major depression [108]. Meanwhile, a considerable number of hydroxyindole $O$-methyltransferase (=acetylserotonin methyltransferase, ASMT) variants is known, which largely differ with regard to enzyme activity [109]. In various cases, this should lead to strongly reduced levels of circulating melatonin. Several variants, in particular those with low or disrupted activity, were associated with autism spectrum disorders [109-112], ADHD (attention-deficit and hyperactivity disorder) [109,113], recurrent depression [114], bipolar disorder [109,115] and intellectual disability [109]. Polymorphisms in the $M T_{1}$ receptor gene (MTNR1A) were also found to be associated with ADHD [113], with schizophrenia [116], coronary artery disease [117], polycystic ovary syndrome [118] and calcium nephrolithiasis [119]. Considerable attention has been paid to the polymorphism of the $M T_{2}$ receptor gene (MTNR1B). Variants are thought to be involved in polycystic ovary syndrome [120], rheumatoid arthritis [121], progressive subtypes of multiple sclerosis [122] and, perhaps, adolescent idiopathic scoliosis [123,124]. Importantly, this polymorphism was also associated with metabolic disorders, from elevated fasting glucose and cholesterol to diabetes type 2, as documented in numerous studies (summarized in $[12,125]$ ). 
A gene polymorphism was also studied in the case a melatonin receptor-associated protein, GPR50. This has been identified as a mammalian ortholog of the non-mammalian $\mathrm{Mel}_{1 \mathrm{c}}$ receptor [126]. However, GPR50 is incapable of binding the pineal hormone. This orphan receptor heterodimerizes with $\mathrm{MT}_{1}$, thereby preventing $\mathrm{G}$ protein coupling [127]. Whether the association of GPR50 variants with, e.g., bipolar and seasonal affective disorders and elevated fasting triglycerides has to be explained by interference with melatonergic signaling remains to be unequivocally demonstrated, because GPR50 also interacts with other proteins not related to functions of melatonin ( $c f$. [125]).

Melatonin dysfunction can be assumed to exist if the nocturnal values of the circulating hormone drop below a certain threshold that does no longer warrant sufficient receptor activation. With regard to the differences in affinity between $\mathrm{MT}_{1}$ and $\mathrm{MT}_{2}$ receptors $\left(\mathrm{pK}_{\mathrm{i}}\right.$-values of about 10.09 and 9.42, respectively, in wild-type human receptors [125,128]), reduced melatonin levels should lead first to functional losses in $\mathrm{MT}_{2}$ signaling. This may vary with regard to deviating affinities of mutant receptor variants.

A frequently observed phenomenon is the reduction of nocturnal melatonin in the course of aging [129-132]. The interindividual variability of these losses in melatonin secretion is, however, high. Whilst nighttime values are in some elderly subjects almost indistinguishable from daytime levels, others maintain a fairly well pronounced rhythm with only moderate reductions of the nocturnal peak. Correspondingly, age-related losses have been also demonstrated in melatonin concentrations of human pineals, cerebrospinal fluid, saliva, and in the amounts of the major urinary metabolite, 6-sulfatoxymelatonin (summarized in [125]). As long as the melatonin rhythm is still detectable in an aging individual, a phase-advance of the nocturnal peak is often observed [131], which may be in accordance with the typical age-related shortening of the spontaneous circadian period, which leads, under synchronized conditions, to a change in the phase angle. Several factors can contribute to the reduction of melatonin secretion. In principle, visual input to the SCN, integrity of the SCN and the neuronal connection to the pineal can be affected [131,133-135] as well as the integrity of the pineal itself, which may become, in some cases, progressively calcified [136,137]. As soon as the functioning of the SCN is impaired, the lack of a strong feedback signal by melatonin may further aggravate the functional losses. It should be also kept in mind that the reductions in circulating melatonin may also have considerable consequences for peripheral oscillators, too, and also for oscillator-independent up- and downregulations of genes in many places of the body. Even in these latter cases, this would lead to losses of timing and, thus, temporal coordination of physiological parameters as required for the well-functioning of an organism.

Reductions of melatonin secretion are also observed in remarkably many diseases and disorders. It seems important to discriminate between changes that occur as a consequence of a disease and others that may be causative or contributing factors to disease development and/or progression. This distinction cannot yet be made with certainty in various cases, especially, in those in which the consequences of mutations in receptor genes have not been clarified in terms of changes in affinity and coupling to signaling pathways. Judgments may be more easily made in cases in which the melatonin biosynthetic pathway is impaired by mutations in the Aanat and Asmt genes. This seems to be especially possible in the recently described variants of the ASMT (HIOMT) protein, as far as they are exhibit strongly reduced enzyme activities [109]. From this point of view, the association of such variants with autism spectrum disorders, ADHD, bipolar disorder, and cases of intellectual disability 
has gained a new quality of interpretation. However, it still remains unclear why some other variants that posses approximately normal enzyme activities are sometimes also associated with such disorders. The required clarification may be achieved by investigating differences in regulation, in protein-protein interactions and by determining enzyme stability or proteasomal degradation rates.

Reductions in melatonin largely appear to be the consequence rather than cause in cases of Alzheimer's disease (AD) and other forms of senile dementia [125,131,134,135,138-143], although the lack may further aggravate the disease. Typically, levels of melatonin are by far more strongly decreased than in age-matched controls. Frequently, the melatonin rhythm is, from a certain point on, almost abolished. These changes are often explained by a progressing neurodegeneration in the SCN. Reductions of 6-sulfatoxymelatonin, which would imply corresponding decreases in melatonin, were also observed in cases of age-related macular degeneration [144], which may result from a reduced visual input to the SCN associated by a weakening of the aging oscillator. Reduced melatonin was also observed in cases of another neurodegenerative form of dementia, Pick's disease [139]. Eventual changes in the SCN remain to be studied.

Apart from various other diseases with reduced melatonin, in which either the pineal gland is damaged, e.g., by a hamartoma or a craniopharyngioma, or in which severe changes in the hormonal system are present, such as in hypergonadotrophic hypogonadism (summarized in [125]), a number of conditions exist in which decreases of the pineal hormone are observed, although the causal relationship is not obvious at first glance. This observation includes some neurological disorders, notably a subpopulation of schizophrenics $[145,146]$ and patients with primary obsessive-compulsive disorder [147]. Although major depression is not generally associated with reduced melatonin secretion, this was found in cases of comorbidity with multiple sclerosis [148]. However, subforms of major depression may require a reinvestigation with regard to observed polymorphism of the Aaanat gene, as mentioned above.

Meanwhile, a relatively large body of evidence has accumulated for reductions of melatonin under stressful and painful conditions, however, with considerable interindividual variation. These include several forms of cardiac diseases (coronary heart disease, myocardial infarction, cardiac syndrome X) [149-155], fibromyalgia [125,156], neuralgia [156], migraine [157,158], severe epilepsy [159,160], Menière's disease [161], bulimia [156], critical illness [162-164], postoperative stress [165], acute intermittent porphyria, especially during seizures [166,167], and cases of cancer $[168,169]$.

Decreases in melatonin have been also observed in diabetes type 2 [170,171]. This is of particular interest with regard to the repeatedly demonstrated association of the $M_{2}$ (MTNR1B) polymorphism and the effects of melatonin on islet function and the islet oscillator [49,93]. Therefore, the relationship between melatonin signaling and diabetes type 2 may be more profound than previously believed.

\section{Consequences of Impaired Melatonergic Signaling and Treatment Options}

To draw adequate conclusions, it seems necessary to distinguish between different conditions under which melatonergic dysfunction is observed. A major discrimination has to be made between disorders with and without SCN destruction. As soon as the SCN is damaged by neurodegenerative processes, e.g., in $\mathrm{AD}$, melatonin will not be able to appropriately control the phase of the pacemaker and all $\mathrm{SCN}$-dependent processes can be expected to deteriorate. Of course, intermediate stages do exist, in 
which disease progression is not too much advanced, such that melatonin may be partially effective. However, it may be a misconception to believe that, in cases of a dysfunctional SCN, any treatment with melatonin or synthetic melatonergic agonists would be per se useless. This conclusion is based on our actual understanding of the body's circadian organization as a multioscillator system, which only partially depends on the SCN and which is, in some of its oscillatory elements, susceptible to various different time cues, including nonphotic ones and the message conveyed by melatonin, too. Therefore, melatonin signaling beyond a dysfunctional SCN may be of particular importance to maintain, as far as possible, a coordinated time structure within the organism, by periodic inputs into extra-SCN oscillators and by timely inducing or deinducing gene expression in cells that do not contain melatonin-sensitive oscillators but melatonin-controlled genes.

Unfortunately, this aspect has not been systematically investigated in AD patients, especially not with regard to vegetative functions. The focus of AD studies has usually been put, apart from cognitive parameters, mainly on sleep and behavioral abnormalities, such as sundowning. With regard to its circadian components, sleep is largely dependent on the SCN, but not entirely, and includes a melatonin effect transmitted by thalamic melatonin receptors that favors the generation of sleep spindles, in a thalamo-cortical interplay [172,173]. Whilst melatonin was found not to be generally effective as a soporific agent in AD [174], positive effects were described concerning both sleep improvements and alleviation of behavioral symptoms in a number of patients [175-177].

Under the other condition of a functionally preserved SCN, a further discrimination seems to be necessary. On the one hand, melatonin receptor variants with a deviatant or impaired signal transduction may, in principle, lead to similar (patho-)physiological consequences as reduced melatonin secretion, whether caused by a defective biosynthetic pathway or acquired by aging or disease. However, the options for treatment can be expected to strongly differ. Reduced melatonin levels may be partially corrected by treatment with melatonin or synthetic melatonergic drugs, whereas no such improvement can be achieved in cases of receptor dysfunction. One might believe that mutual functional substitution of $\mathrm{MT}_{1}$ and $\mathrm{MT}_{2}$ receptors, which has, in fact, been observed, may diminish this problem, but these findings cannot be generalized to all tissues and cell types. Differences in signaling pathways of the two receptor subtypes do exist in a cell-specific way (cf. [178]). Although the $\mathrm{MT}_{2}$ receptor, which has lower affinity to its ligand than $\mathrm{MT}_{1}$, may replace to a certain degree a dysfunctional mutant $\mathrm{MT}_{1}$ receptor and though administration of melatonin may partially compensate for the lower affinity, a complete readjustment cannot be achieved, for reasons of differences in the distribution of the subtypes and cell type-specific signaling pathways [178], which exceed the classic inhibition of adenylyl cyclase. In the extreme, activation of the receptor subtypes leads to opposite effects, such as in vasomotor control, where $\mathrm{MT}_{1}$ signaling causes constriction, but $\mathrm{MT}_{2}$ activation dilation [179].

It may still be too early to translate these general considerations into an advice for treatment. In particular, the actual body of knowledge on human melatonin receptor gene polymorphisms may shed light on relationships to etiologies of diseases and disorders, but it does not yet provide sufficient information on the molecular and cell biological consequences. To what extent gene variants or other SNPs that may alter receptor gene expression really cause quantitative changes in expression levels, alterations in $\mathrm{G}$ protein coupling and other downstream effects remains to be studied on a broader scale. A human variant of $\mathrm{MT}_{1}$ with significantly reduced binding capacity $\left(B_{\max }\right)$ has been described 
in an earlier study [180]. A more recent investigation has identified a number of $\mathrm{MT}_{2}$ variants with altered binding and signaling properties [181]. Four variants were incapable of binding melatonin, 11 others did not show $\mathrm{G}_{\mathrm{i}}$ signaling, another one was devoid of ERK activation, and numerous rare loss-of-function variants were also identified. Studies like this one should stimulate researchers to further investigate the cell biological consequences of receptor polymorphisms more systematically with regard to the various diseases and disorders associated with melatonin signaling. The identification of changes in expression and signaling is particularly important with regard to the options of treatment. Variants defective in melatonin binding and/or G protein coupling will be resistant to melatonin therapy. Moreover, variants should not only be seen under the aspect of disrupted function, since the possibility of an undesired receptor overexpression may likewise lead to pathological consequences. This is reflected by the actual discussion concerning the enhanced expression of the $\mathrm{MT}_{2}$ risk variant, the G-allele of the MTNR1B gene, for diabetes type 2 [182]. In fact, carriers of a gain-of-function mutant should not be treated with melatonin. Whether antagonists might be helpful in such cases, as suggested, remains to be clarified, especially with regard to the multitude of side effects that can be expected. Reductions in melatonin levels that are observed in diabetes type 2, as mentioned above, may already contribute to weakening of $\mathrm{MT}_{2}$ signaling. However, it should be noted that loss-of-function mutants of the MTNR1B gene were also associated with diabetes type 2 [181].

Relative to the genetic changes in melatonergic signaling, the situation appears to be much clearer in cases in which melatonin levels are decreased because of aging or disease, in the presence of a relatively well-functioning SCN. Even if the focus of this article is mainly laid on the extra-SCN oscillators and peripheral effects not requiring an oscillator, the ensemble of clocks in the multioscillator system may be more easily orchestrated as long as the pacemaker is sufficiently working.

Regarding this condition, the major question is that of whether a replacement therapy can be achieved. A major obstacle at this aim is the short halflife of circulating melatonin, which is mostly in the range of 20-30 min, sometimes less, but maximally about $45 \min$ [173,183]. Two different attempts have been made to circumvent this problem, the use of controlled-release tablets of melatonin and of synthetic melatonergic agonists with a longer halflife. Since the properties of the respective pharmaceutical products have been repeatedly reviewed on a comparative basis with regard to efficacy, pharmacology and metabolism [125,173,184-187], these details will only be briefly discussed. The indolic agonist $\beta$-methyl-6-chloromelatonin (TIK-301) [188] has a halflife in the range of $1 \mathrm{~h}$ and, compared to melatonin, an approximately same affinity to $\mathrm{MT}_{1}$ but a higher one to $\mathrm{MT}_{2}$. The naphthalenic agonist agomelatine has a halflife in the range of $1-2 \mathrm{~h}$ and affinities to both receptors slightly above those of melatonin [189]. Another nonindolic agonist, ramelteon, also exhibits a halflife of 1-2 h, but has higher affinities to both receptors [128,190]. However, one of the major metabolites of this latter compound retains some $10 \%$ of the receptor affinities, but has a halflife $2-5 \mathrm{~h}$ longer than the parent drug, properties that result in metabolite concentrations 20-100 times higher than ramelteon [181,191]. Properties of other, still investigational agonists have been summarized elsewhere [125,192,193].

To date, the value of these drugs cannot be judged with certainty based on nocturnal time profiles of these compounds and their metabolites nor of effects in peripheral tissues. The endpoints tested are almost exclusively related to the central nervous system and mainly concern sleep, but also the 
readjustment of circadian functions with focus on SCN-dependent effects, and to antidepressive actions that largely extend to subtype-specific serotonergic antagonisms. Sleep may be taken as a physiological function that might be suitable for judging on complete efficacy in a substitution therapy. The general observation is that all melatonergic drugs are effective in reducing sleep latency, but that all of them, despite some statistically demonstrable improvements, are not capable of fully restoring sleep maintenance $[125,186]$. This may be indicative of insufficient efficacy in terms of a substitution therapy.

Nevertheless, the actual inability of satisfactorily restituting a nocturnal melatonin profile that both avoids strongly supraphysiological levels after drug intake, with the eventual consequence of receptor desensitization [178], and an untimely drop of the circulating agonist in the second half of the night, should not retain researchers from investigating the effects of melatonin on peripheral functions in elderly or diseased individuals. For resychronizing the pacemaker, relatively small amounts of immediate-release melatonin or other melatonergic drugs are sufficient $[125,186]$. Therefore, a chance may exist to likewise resynchronize peripheral and other extra-SCN oscillators by short-acting melatonin pulses. This should be seen as a possible way of improving the functioning of a gradually deteriorated multioscillator system, even under conditions of a partially defective pacemaker. The feasibility of this concept remains to be studied.

\section{Conclusions}

Various lines of evidence have shown that melatonin plays a role in the appropriate functioning of several extra-SCN oscillators. This includes results from melatonin-deficient animals, receptor knockouts and phase-shifting experiments in explants. These investigations have not yet been extended to a larger number of oscillators. Nevertheless, systematic studies into this direction seem to be worth-while, promising and, in this author's belief, necessary. As a major orchestrating chronobiological signal molecule, melatonin may be effective in coordinating numerous rhythms. Progress in this regard may open our view on the intraorganismal timing within the multioscillator system. Moreover, this kind of research has the potential for improving the persistence, amplitudes and coordinated phasing of oscillators under conditions of melatonergic dysfunction. This may be of particular value under conditions of reduced melatonin, as it occurs in elderlies and in various pathologies. Recent data on defective melatonin biosynthesis provide cases in which administration of melatonin or other melatonergic drugs seems recommendable. Moreover, melatonergic treatment may be helpful in patients in whom the SCN is poorly functional, because of neurodegeneration or impaired light input. It is the hope that this may help maintain a minimum of rhythmic time structures in individuals who lack a sufficiently strong circadian signal originating from the SCN.

At the present state of knowledge, a complete replacement therapy has not been achieved, if possible at all. A desiderate may be to reconstruct a normal nocturnal time profile of melatonin. Whether or to what extent this will be really necessary, as long as only chronobiological effects are intended, remains to be clarified. Synchronizing effects may already be attained at relatively moderate doses of immediate-release melatonin, as known from SCN-dependent rhythms. This is the more important as long-term tolerability will be a decisive issue for such treatments. The toxicological concerns related to the use of synthetic agonists have also to be taken into consideration [125,186,187]. 
There are additional physiological or pathophysiological limits to the use of melatonin and synthetic melatonergic agonists, as discussed, for example in the case of the G-allele of the MTNR1B gene, and various other conditions which have been identified or, at least, assumed to have unfavorable consequences $[125,173,187]$. In general, however, melatonin is mostly well tolerated, and low, chronobiologically effective doses should be preferred in comparison to the much higher recommended doses of the synthetic agonists.

\section{Conflict of Interest}

The author declares no conflict of interest.

\section{References}

1. Hardeland, R.; Cardinali, D.P.; Srinivasan, V.; Spence, D.W.; Brown, G.M.; Pandi-Perumal, S.R. Melatonin-A pleiotropic, orchestrating regulator molecule. Prog. Neurobiol. 2011, 93, 350-384.

2. Tricoire, H.; Locatelli, A.; Chemineau, P.; Malpaux, B. Melatonin enters the cerebrospinal fluid through the pineal recess. Endocrinology 2002, 143, 84-90.

3. Tricoire, H.; Møller, M.; Chemineau, P.; Malpaux, B. Origin of cerebrospinal fluid melatonin and possible function in the integration of photoperiod. Reprod. Suppl. 2003, 61, 311-321.

4. Stehle, J.H.; von Gall, C.; Korf, H.W. Melatonin: A clock-output, a clock-input. J. Neuroendocrinol. 2003, 15, 383-389.

5. Perreau-Lenz, S.; Kalsbeek, A.; Garidou, M.L.; Wortel, J.; van der Vliet, J.; van Heijningen, C.; Simonneaux, V.; Pévet, P.; Buijs, R.M. Suprachiasmatic control of melatonin synthesis in rats: Inhibitory and stimulatory mechanisms. Eur. J. Neurosci. 2003, 17, 221-228.

6. Hardeland, R. Melatonin, hormone of darkness and more-Occurrence, control mechanisms, actions and bioactive metabolites. Cell Mol. Life Sci. 2008, 65, 2001-2018.

7. Reiter, R.J. Melatonin: The chemical expression of darkness. Mol. Cell Endocrinol. 1991, 79, C153-C159.

8. Reiter, R.J. The melatonin rhythm: Both a clock and a calendar. Experientia 1993, 49, 654-664.

9. Lewy, A.J.; Ahmed, S.; Jackson, J.M.; Sack, R.L. Melatonin shifts human circadian rhythms according to a phase-response curve. Chronobiol. Int. 1992, 9, 380-392.

10. Burgess, H.J.; Revell, V.L.; Eastman, C.I. A three pulse phase response curve to three milligrams of melatonin in humans. J. Physiol. 2008, 586, 639-647.

11. Honma, K.; Honma, S. The SCN-independent clocks, methamphetamine and food restriction. Eur. J. Neurosci. 2009, 30, 1707-1717.

12. Hardeland, R.; Madrid, J.A.; Tan, D.-X.; Reiter, R.J. Melatonin, the circadian multioscillator system and health: The need for detailed analyses of peripheral melatonin signaling. J. Pineal Res. 2012, 52, 139-166.

13. Silver, R.; Schwartz, W.J. The suprachiasmatic nucleus is a functionally heterogeneous timekeeping organ. Methods Enzymol. 2005, 393, 451-465.

14. Belle, M.D.; Diekman, C.O.; Forger, D.B.; Piggins, H.D. Daily electrical silencing in the mammalian circadian clock. Science 2009, 326, 281-284. 
15. Zhang, E.E.; Liu, A.C.; Hirota, T.; Miraglia; L.J.; Welch, G.; Pongsawakul, P.Y.; Liu, X.; Atwood, A.; Huss, J.W., 3rd; Janes, J.; et al. A genome-wide RNAi screen for modifiers of the circadian clock in human cells. Cell 2009, 139, 199-210.

16. Zhang, E.E.; Kay, S.A. Clocks not winding down: Unravelling circadian networks. Nat. Rev. Mol. Cell Biol. 2010, 11, 764-776.

17. Yamada, Y.; Forger, D. Multiscale complexity in the mammalian circadian clock. Curr. Opin. Genet. Dev. 2010, 20, 626-633.

18. Wu, T.; Jin, Y.; Ni, Y.; Zhang, D.; Kato, H.; Fu, Z. Effects of light cues on re-entrainment of the food-dominated peripheral clocks in mammals. Gene 2008, 419, 27-34.

19. Wu, T.; Ni, Y.; Zhuge, F.; Fu, Z. Resetting process of peripheral circadian gene expression after the combined reversal of feeding schedule and light/dark cycle via a 24 -h light period transition in rats. Physiol. Res. 2010; 59, 581-590.

20. Tosini, G.; Menaker, M. Circadian rhythms in cultured mammalian retina. Science 1996, 272, $419-421$.

21. Dinet, V.; Korf, H.W. Impact of melatonin receptors on pCREB and clock-gene protein levels in the murine retina. Cell Tissue Res. 2007, 330, 29-34.

22. Dinet, V.; Ansari, N.; Torres-Farfan, C.; Korf, H.W. Clock gene expression in the retina of melatonin-proficient $(\mathrm{C} 3 \mathrm{H})$ and melatonin-deficient (C57BL) mice. J. Pineal Res. 2007, 42, 83-91.

23. Storch, K.F.; Paz, C.; Signorovitch, J.; Raviola, E.; Pawlyk, B.; Li, T.; Weitz, C.J. Intrinsic circadian clock of the mammalian retina: Importance for retinal processing of visual information. Cell 2007, 130, 730-741.

24. Storch, K.F.; Paz, C.; Signorovitch, J.; Raviola, E.; Pawlyk, B.; Li, T.; Weitz, C.J. Physiological importance of a circadian clock outside the suprachiasmatic nucleus. Cold Spring Harbor Symp. Quant. Biol. 2007, 72, 307-318.

25. Ruan, G.X.; Allen, G.C.; Yamazaki, S.; McMahon, D.G. An autonomous circadian clock in the inner mouse retina regulated by dopamine and GABA. PLoS Biol. 2008, 6, e249.

26. Tosini, G.; Pozdeyev, N.; Sakamoto, K.; Iuvone, P.M. The circadian clock system in the mammalian retina. Bioessays 2008, 30, 624-633.

27. Ruan, G.X.; Gamble, K.L.; Risner, M.L.; Young, L.A.; McMahon, D.G. Divergent roles of clock genes in retinal and suprachiasmatic nucleus circadian oscillators. PLoS One 2012, 7, e38985.

28. Miñana-Solis, M.C.; Ángeles-Castellanos, M.; Feillet, C.; Pévet, P.; Challet, E.; Escobar, C. Differential effects of a restricted feeding schedule on clock-gene expression in the hypothalamus of the rat. Chronobiol. Int. 2009, 26, 808-820.

29. Bass, J.; Takahashi, J.S. Circadian integration of metabolism and energetics. Science 2010, 330, 1349-1354.

30. Uz, T.; Akhisaroglu, M.; Ahmed, R.; Manev, H. The pineal gland is critical for circadian Period1 expression in the striatum and for circadian cocaine sensitization in mice. Neuropsychopharmacology 2003, 28, 2117-2123.

31. Imbesi, M.; Arslan, A.D.; Yildiz, S.; Sharma, R.; Gavin, D.; Tun, N.; Manev, H.; Uz, T. The melatonin receptor MT1 is required for the differential regulatory actions of melatonin on neuronal "clock" gene expression in striatal neurons in vitro. J. Pineal Res. 2009, 46, 87-94. 
32. Jilg, A.; Lesny, S.; Peruzki, N.; Schwegler, H.; Selbach, O.; Dehghani, F.; Stehle, J.H. Temporal dynamics of mouse hippocampal clock gene expression support memory processing. Hippocampus 2010, 20, 377-388.

33. Kaneko, K.; Yamada, T.; Tsukita, S.; Takahashi, K.; Ishigaki, Y.; Oka, Y.; Katagiri, H. Obesity alters circadian expressions of molecular clock genes in the brainstem. Brain Res. 2009, 1263, $58-68$.

34. Von Gall, C.; Garabette, M.L.; Kell, C.A.; Frenzel, S.; Dehghani, F.; Schumm-Draeger, P.M.; Weaver, D.R.; Korf, H.W.; Hastings, M.H.; Stehle, J.H. Rhythmic gene expression in pituitary depends on heterologous sensitization by the neurohormone melatonin. Nat. Neurosci. 2002, 5, 234-238.

35. Dardente, H.; Menet, J.S.; Poirel, V.J.; Streicher, D.; Gauer, F.; Vivien-Roels, B.; Klosen, P.; Pévet, P.; Masson-Pévet, M. Melatonin induces Cryl expression in the pars tuberalis of the rat. Brain Res. Mol. Brain Res. 2003, 114, 101-106.

36. Von Gall, C.; Weaver, D.R.; Moek, J.; Jilg, A.; Stehle, J.H.; Korf, H.W. Melatonin plays a crucial role in the regulation of rhythmic clock gene expression in the mouse pars tuberalis. Ann. N.Y. Acad. Sci. 2005, 1040, 508-511.

37. Jilg, A.; Moek, J.; Weaver, D.R.; Korf, H.W.; Stehle, J.H.; von Gall, C. Rhythms in clock proteins in the mouse pars tuberalis depend on MT1 melatonin receptor signalling. Eur. J. Neurosci. 2005, 22, 2845-2854.

38. Johnston, J.D.; Tournier, B.B.; Andersson, H.; Masson-Pévet, M.; Lincoln, G.A.; Hazlerigg, D.G. Multiple effects of melatonin on rhythmic clock gene expression in the mammalian pars tuberalis. Endocrinology 2006, 147, 959-965.

39. Dardente, H. Does a melatonin-dependent circadian oscillator in the pars tuberalis drive prolactin seasonal rhythmicity? J. Neuroendocrinol. 2007, 19, 657-666.

40. Unfried, C.; Burbach, G.; Korf, H.W.; von Gall, C. Melatonin receptor 1-dependent gene expression in the mouse pars tuberalis as revealed by cDNA microarray analysis and in situ hybridization. J. Pineal Res. 2010, 48, 148-156.

41. Bur, I.M.; Zouaoui, S.; Fontanaud, P.; Coutry, N.; Molino, F.; Martin, A.O.; Mollard, P.; Bonnefont, $\mathrm{X}$. The comparison between circadian oscillators in mouse liver and pituitary gland reveals different integration of feeding and light schedules. PLoS One 2010, 5, e15316.

42. Guillaumond, F.; Becquet, D.; Boyer, B.; Bosler, O.; Delaunay, F.; Franc, J.L.; François-Bellan, A.M. DNA microarray analysis and functional profile of pituitary transcriptome under core-clock protein BMAL1 control. Chronobiol. Int. 2012, 29, 103-130.

43. Torres-Farfan, C.; Serón-Ferré, M.; Dinet, V.; Korf, H.W. Immunocytochemical demonstration of day/night changes of clock gene protein levels in the murine adrenal gland: Differences between melatonin-proficient $(\mathrm{C} 3 \mathrm{H})$ and melatonin-deficient (C57BL) mice. J. Pineal Res. 2006, 40, 64-70.

44. Chung, S.; Son, G.H.; Kim, K. Adrenal peripheral oscillator in generating the circadian glucocorticoid rhythm. Ann. N.Y. Acad. Sci. 2011, 1220, 71-81.

45. Chung, S.; Son, G.H.; Kim, K. Circadian rhythm of adrenal glucocorticoid: Its regulation and clinical implications. Biochim. Biophys. Acta 2011, 1812, 581-591. 
46. Son, G.H.; Chung, S.; Kim, K. The adrenal peripheral clock: Glucocorticoid and the circadian timing system. Front. Neuroendocrinol. 2011, 32, 451-465.

47. Peschke, E.; Peschke, D. Evidence for a circadian rhythm of insulin release from perifused rat pancreatic islets. Diabetologia 1998, 41, 1085-1092.

48. Mühlbauer, E.; Wolgast, S.; Finckh, U.; Peschke, D.; Peschke, E. Indication of circadian oscillations in the rat pancreas. FEBS Lett. 2004, 564, 91-96.

49. Peschke, E. Melatonin, endocrine pancreas and diabetes. J. Pineal Res. 2008, 44, 26-40.

50. Oishi, K.; Fukui, H.; Ishida, N. Rhythmic expression of BMAL1 mRNA is altered in Clock mutant mice: Differential regulation in the suprachiasmatic nucleus and peripheral tissues. Biochem. Biophys. Res. Commun. 2000, 268, 164-171

51. Stokkan, K.A.; Yamazaki, S.; Tei, H.; Sakaki, Y.; Menaker, M. Entrainment of the circadian clock in the liver by feeding. Science 2001, 291, 490-493.

52. Storch, K.F.; Lipan, O.; Leykin, I.; Viswanathan, N.; Davis, F.C.; Wong, W.H.; Weitz, C.J. Extensive and divergent circadian gene expression in liver and heart. Nature 2002, 417, 78-83.

53. Kornmann, B.; Schaad, O.; Bujard, H.; Takahashi, J.S.; Schibler, U. System-driven and oscillator-dependent circadian transcription in mice with a conditionally active liver clock. PLoS Biol. 2007, 5, e34.

54. Kornmann, B.; Schaad, O.; Reinke, H.; Saini, C.; Schibler, U. Regulation of circadian gene expression in liver by systemic signals and hepatocyte oscillators. Cold Spring Harb. Symp. Quant. Biol. 2007, 72, 319-330.

55. Lamia, K.A.; Storch, K.F.; Weitz, C.J. Physiological significance of a peripheral tissue circadian clock. Proc. Natl. Acad. Sci. USA 2008, 105, 15172-15177.

56. Hirao, A.; Nagahama, H.; Tsuboi, T.; Hirao, M.; Tahara, Y.; Shibata, S. Combination of starvation interval and food volume determines the phase of liver circadian rhythm in Per2::Luc knock-in mice under two meals per day feeding. Am. J. Physiol. Gastrointest. Liver Physiol. 2010, 299, G1045-G1053.

57. Hsieh, M.C.; Yang, S.C.; Tseng, H.L.; Hwang, L.L.; Chen, C.T.; Shieh, K.R. Abnormal expressions of circadian-clock and circadian clock-controlled genes in the livers and kidneys of long-term, high-fat-diet-treated mice. Int. J. Obes. 2010, 34, 227-239.

58. Motosugi, Y.; Ando, H.; Ushijima, K.; Maekawa, T.; Ishikawa, E.; Kumazaki, M.; Fujimura, A. Tissue-dependent alterations of the clock gene expression rhythms in leptin-resistant Zucker diabetic fatty rats. Chronobiol. Int. 2011, 28, 968-972.

59. Mazzoccoli, G.; Francavilla, M.; Pazienza, V.; Benegiamo, G.; Piepoli, A.; Vinciguerra, M.; Giuliani, F.; Yamamoto, T.; Takumi, T. Differential patterns in the periodicity and dynamics of clock gene expression in mouse liver and stomach. Chronobiol. Int. 2012, 29, 1300-1311.

60. Takahashi, K.; Yamada, T.; Tsukita, S.; Kaneko, K.; Shirai, Y.; Munakata, Y.; Ishigaki, Y.; Imai, J.; Uno, K.; Hasegawa, Y.; et al. Chronic mild stress alters circadian expressions of molecular clock genes in the liver. Am. J. Physiol. Endocrinol. Metab. 2013, 304, E301-E309.

61. Gómez-Santos, C.; Gómez-Abellán, P.; Madrid, J.A.; Hernández-Morante, J.J.; Lujan, J.A.; Ordovas, J.M.; Garaulet, M. Circadian rhythm of clock genes in human adipose explants. Obesity 2009, 17, 1481-1485. 
62. Young, M.E.; Razeghi, P.; Taegtmeyer, H. Clock genes in the heart: Characterization and attenuation with hypertrophy. Circ. Res. 2001, 88, 1142-1150.

63. Young, M.E.; Wilson, C.R.; Razeghi, P.; Guthrie, P.H.; Taegtmeyer, H. Alterations of the circadian clock in the heart by streptozotocin-induced diabetes. J. Mol. Cell Cardiol. 2002, 34, 223-231.

64. Jeyaraj, D.; Haldar, S.M.; Wan, X.; McCauley, M.D.; Ripperger, J.A.; Hu, K.; Lu, Y.; Eapen, B.L.; Sharma, N.; Ficker, E.; et al. Circadian rhythms govern cardiac repolarization and arrhythmogenesis. Nature 2012, 483, 96-99.

65. Zeman, M.; Herichová, I. Melatonin and clock genes expression in the cardiovascular system. Front. Biosci. 2013, 5, 743-753.

66. Kennaway, D.J.; Varcoe, T.J.; Mau, V.J. Rhythmic expression of clock and clock-controlled genes in the rat oviduct. Mol. Hum. Reprod. 2003, 9, 503-507.

67. Fu, L.; Patel, M.S.; Bradley, A.; Wagner, E.F.; Karsenty, G. The molecular clock mediates leptin-regulated bone formation. Cell 2005, 122, 803-815.

68. Fu, L.; Patel, M.S.; Karsenty, G. The circadian modulation of leptin-controlled bone formation. Prog. Brain Res. 2006, 153, 177-188.

69. Yagita, K.; Tamanini, F.; van Der Horst, G.T.; Okamura, H. Molecular mechanisms of the biological clock in cultured fibroblasts. Science 2001, 292, 278-281.

70. Welsh, D.K.; Yoo, S.H.; Liu, A.C.; Takahashi, J.S.; Kay, S.A. Bioluminescence imaging of individual fibroblasts reveals persistent, independently phased circadian rhythms of clock gene expression. Curr. Biol. 2004, 14, 2289-2295.

71. Hardeland, R.; Coto-Montes, A.; Poeggeler, B. Circadian rhythms, oxidative stress and antioxidative defense mechanisms. Chronobiol. Int. 2003, 20, 921-962.

72. Hardeland, R. Antioxidative protection by melatonin-Multiplicity of mechanisms from radical detoxification to radical avoidance. Endocrine 2005, 27, 119-130.

73. Baydas, G.; Gursu, M.F.; Yilmaz, S.; Canpolat, S.; Yasar, A.; Cikim, G.; Canatan H. Daily rhythms of glutathione peroxidase activity, lipid peroxidation and glutathione levels in tissues of pinealectomized rats. Neurosci. Lett. 2002, 323, 195-198.

74. Pablos, M.I.; Reiter, R.J.; Ortiz, G.G.; Guerrero, J.M.; Agapito, M.T.; Chuang, J.I.; Sewerynek, E. Rhythms of glutathione peroxidase and glutathione reductase in brain of chick and their inhibition by light. Neurochem. Int 1998, 32, 69-75.

75. Reiter, R.J.; Tan, D.-X.; Mayo, J.C.; Sainz, R.M.; Leon, J.; Czarnocki, Z. Melatonin as an antioxidant: Biochemical mechanisms and pathophysiological implications in humans. Acta Biochim. Pol. 2003, 50, 1129-1146.

76. Pandi-Perumal, S.R.; Srinivasan, V.; Maestroni, G.J.M.; Cardinali, D.P.; Poeggeler, B.; Hardeland, R. Melatonin: Nature's most versatile biological signal? FEBS J. 2006, 273, 2813-2838.

77. Hardeland, R.; Poeggeler, B. Melatonin beyond its classical functions. Open Physiol. J. 2008, 1, $1-23$.

78. Hardeland, R. Diurnal variations in inducibility of hepatic tyrosine aminotransferase. Int. J. Biochem. 1973, 4, 357-364.

79. Morris, J.E.; Peraino, C. Immunochemical studies of serine dehydratase and ornithine aminotransferase regulation in rat liver in vivo. J. Biol. Chem. 1976, 251, 2571-2578. 
80. Peraino, C.; Morris, J.E.; Shenoy, S.T. Evidence for different mechanisms in the circadian and glucocorticoid control of rat liver ornithine aminotransferase synthesis. Life Sci. 1976, 19, 1435-1437.

81. Kiessling, S.; Eichele, G.; Oster, H. Adrenal glucocorticoids have a key role in circadian resynchronization in a mouse model of jet lag. J. Clin. Invest. 2010, 120, 2600-2609.

82. Balsalobre, A.; Brown, S.A.; Marcacci, L.; Tronche, F.; Kellendonk, C.; Reichardt, H.M.; Schütz, G.; Schibler, U. Resetting of circadian time in peripheral tissues by glucocorticoid signaling. Science 2000, 289, 2344-2347.

83. Noguchi, T.; Ikeda, M.; Ohmiya, Y.; Nakajima, Y. A dual-color luciferase assay system reveals circadian resetting of cultured fibroblasts by co-cultured adrenal glands. PLoS One 2012, 7, e37093.

84. Wu, X.; Yu, G.; Parks, H.; Hebert, T.; Goh B.C.; Dietrich, M.A.; Pelled, G.; Izadpanah, R.; Gazit, D.; Bunnell, B.A.; et al. Circadian mechanisms in murine and human bone marrow mesenchymal stem cells following dexamethasone exposure. Bone 2008, 42, 861-870.

85. Le Minh, N.; Damiola, F.; Tronche, F.; Schütz, G.; Schibler, U. Glucocorticoid hormones inhibit food-induced phase-shifting of peripheral circadian oscillators. EMBO J. 2001, 20, 7128-7136.

86. Gibbs, J.E.; Beesley, S.; Plumb, J.; Singh, D.; Farrow, S.; Ray, D.W.; Loudon, A.S. Circadian timing in the lung; a specifoc role for bronchiolar epithelial cells. Endocrinology 2009, 150, $268-276$.

87. Torres-Farfan, C.; Richter, H.G.; Rojas-García, P.; Vergara, M.; Forcelledo, M.L.; Valladares, L.E.; Torrealba, F.; Valenzuela, G.J.; Serón-Ferré, M. mt1 Melatonin receptor in the primate adrenal gland: Inhibition of adrenocorticotropin-stimulated cortisol production by melatonin. J. Clin. Endocrinol. Metab. 2003, 88, 450-458.

88. Doyle, S.E.; Grace, M.S.; McIvor, W.; Menaker, M. Circadian rhythms of dopamine in mouse retina: The role of melatonin. Vis. Neurosci. 2002, 19, 593-601.

89. Pozdeyev, N.; Tosini, G.; Li, L.; Ali, F.; Rozov, S.; Lee, R.H.; Iuvone, P.M. Dopamine modulates diurnal and circadian rhythms of protein phosphorylation in photoreceptor cells of mouse retina. Eur. J. Neurosci. 2008, 27, 2691-2700.

90. Iuvone, P.M.; Tosini, G.; Pozdeyev, N.; Haque, R.; Klein, D.C.; Chaurasia, S.S. Circadian clocks, clock networks, arylalkylamine $N$-acetyltransferase, and melatonin in the retina. Prog. Retin. Eye Res. 2005, 24, 433-456.

91. Coon, S.L.; del Olmo, E.; Young, W.S., 3rd; Klein, D.C. Melatonin synthesis enzymes in Macaca mulatta: Focus on arylalkylamine $N$-acetyltransferase (EC 2.3.1.87). J. Clin. Endocrinol. Metab. 2002, 87, 4699-4706.

92. Klein, D.C. Arylalkylamine $N$-acetyltransferase: “The timezyme”. J. Biol. Chem. 2007, 282, 4233-4237.

93. Mühlbauer, E.; Gross, E.; Labucay, K.; Wolgast, S.; Peschke, E. Loss of melatonin signalling and its impact on circadian rhythms in mouse organs regulating blood glucose. Eur. J. Pharmacol. 2009, 606, 61-71.

94. Tanioka, M.; Yamada, H.; Doi, M.; Bando, H.; Yamaguchi, Y.; Nishigori, Y.; Okamura, H. Molecular clocks in mouse skin. J. Invest. Dermatol. 2009, 129, 1225-1231. 
95. Akashi, M.; Soma, H.; Yamamoto, T.; Tsugitomi, A.; Yamashita, S.; Yamamoto, T.; Nishida, E.; Yasuda, A.; Liao, J.K.; Node, K. Noninvasive method for assessing the human circadian clock using hair follicle cells. Proc. Natl. Acad. Sci. USA 2010, 107, 15643-15648.

96. Watanabe, M.; Hida, A.; Kitamura, S.; Enomoto, M.; Ohsawa, Y.; Katayose, Y.; Nozaki, K.; Moriguchi, Y.; Anitake, S.; Higuchi, S.; et al. Rhythmic expression of circadian clock genes in human leukocytes and beard hair follicle cells. Biochem. Biophys. Res. Commun. 2012, 425, 902-907.

97. Slominski, A.; Wortsman, J.; Tobin, D.J. The cutaneous serotoninergic/melatoninergic system: Securing a place under the sun. FASEB J. 2005, 19, 176-194.

98. Slominski, A.; Wortsman, J.; Tuckey, R.C.; Paus, R. Differential expression of HPA axis homolog in the skin. Mol. Cell Endocrinol. 2007, 265-266, 143-149.

99. Slominski, A.T.; Zmijewski, M.A.; Skobowiat, C.; Zbytek, B.; Slominski, R.M.; Steketee, J.D. Sensing the environment: Regulation of local and global homeostasis by the skin neuroendocrine system. Adv. Anat. Embryol. Cell Biol. 2012, 212, 1-115.

100. Deacon, S.; Arendt, J. Melatonin-induced temperature suppression and its acute phase-shifting effects correlated in a dose-dependent manner in humans. Brain Res. 1995, 688, 77-85.

101. Dawson, D.; Gibbon, S.; Singh, P. The hypothermic effect of melatonin on core body temperature: Is more better? J. Pineal Res. 1996, 20, 192-197.

102. Cajochen, C.; Kräuchi, K.; Wirz-Justice, A. Role of melatonin in the regulation of human circadian rhythms and sleep. J. Neuroendocrinol. 2003, 15, 432-437.

103. Gubin, D.G.; Gubin, G.D.; Waterhouse, J.; Weinert, D. The circadian body temperature rhythm in the elderly: Effect of single daily melatonin dosing. Chronobiol. Int. 2006, 23, 639-658.

104. Buhr, E.D.; Yoo, S.H.; Takahashi, J.S. Temperature as a universal resetting cue for mammalian circadian oscillators. Science 2010, 330, 379-385.

105. Brown, S.A.; Zumbrunn, G.; Fleury-Olela, F.; Preitner, N.; Schibler, U. Rhythms of mammalian body temperature can sustain peripheral circadian clocks. Curr. Biol. 2002, 12, 1574-1583.

106. Saini, C.; Morf, J.; Stratmann, M.; Gos, P. Schibler, U. Simulated body temperature rhythms reveal the phase-shifting behavior and plasticity of mammalian circadian oscillators. Genes Dev. 2012, 26, 567-580.

107. Weinert, D. Circadian temperatue variation and ageing. Aging Res. Rev. 2010, 9, 51-60.

108. Soria, V.; Martínez-Amorós, E.; Escaramís, G.; Valero, J.; Crespo, J.M.; Gutiérrez-Zotes, A.; Bayés, M.; Martorell, L.; Vilella, E.; Estivill, X.; et al. Resequencing and association analysis of arylalkylamine $N$-acetyltransferase (AANAT) gene and its contribution to major depression susceptibility. J. Pineal Res. 2010, 49, 35-44.

109. Goubran Botros, H.; Legrand, P.; Pagan, C.; Bondet, V.; Weber, P.; Ben-Abdallah, M.; Lemière, N.; Huguet, G.; Bellalou, J.; Maronde, E.; et al. Crystal structure and functional mapping of human ASMT, the last enzyme of the melatonin synthesis pathway. J. Pineal Res. 2013, 54, 46-57.

110. Toma, C.; Rossi, M.; Sousa, I.; Blasi, F.; Bacchelli, E.; Alen, R.; Vanhala, R.; Monaco, A.P.; Järvelä, I.; Maestrini, E.; International Molecular Genetic Study of Autism Consortium. Is ASMT a susceptibility gene for autism spectrum disorders? A replication study in European populations. Mol. Psychiatr. 2007, 12, 977-999. 
111. Melke, J.; Goubran Botros, H.; Chaste, P.; Betancur, C.; Nygren, G.; Anckarsäter, H.; Rastam, M.; Ståhlberg, O.; Gillberg, I.C.; Delorme, R.; et al. Abnormal melatonin synthesis in autism spectrum disorders. Mol. Psychiatr. 2008, 13, 90-98.

112. Jonsson, L.; Ljunggren, E.; Bremer, A.; Pedersen, C.; Landén, M.; Thuresson, K.; Giacobini, M.; Melke, J. Mutation screening of melatonin-related genes in patients with autism spectrum disorders. BMC Med. Genomics 2010, 3, 10.

113. Chaste, P.; Clement, N.; Botros, H.G.; Guillaume, J.L.; Konyukh, M.; Pagan, C.; Scheid, I.; Nygren, G.; Anckarsäter, H.; Rastam, M.; et al. Genetic variations of the melatonin pathway in patients with attention-deficit and hyperactivity disorders. J. Pineal Res. 2011, 51, 394-399.

114. Gałecki, P.; Szemraj, J.; Bartosz, G.; Bieńkiewicz, M.; Gałecka, E.; Florkowski, A.; Lewiński, A.; Karbownik-Lewińska, M. Single-nucleotide polymorphisms and mRNA expression for melatonin synthesis rate-limiting enzyme in recurrent depressive disorder. J. Pineal Res. 2010, 48, 311-317.

115. Etain, B.; Dumaine, A.; Bellivier, F.; Pagan, C.; Francelle, L.; Goubran-Botros, H.; Moreno, S.; Deshommes, J.; Moustafa, K.; le Dudal, K.; et al. Genetic and functional abnormalities of the melatonin biosynthesis pathway in patients with bipolar disorder. Hum. Mol. Genet. 2012, 21, 4030-4037.

116. Park, H.J.; Park, J.K.; Kim, S.K.; Cho, A.R.; Kim, J.W.; Yim, S.V.; Chung, J.H. Association of polymorphism in the promoter of the melatonin receptor $1 \mathrm{~A}$ gene with schizophrenia and with insomnia symptoms in schizophrenia patients. J. Mol. Neurosci. 2011, 45, 304-308.

117. Samimi-Fard, S.; Abreu-Gonzalez, P.; Dominguez-Rodriguez, A.; Jimenez-Sosa, A. A case - Control study of melatonin receptor type 1A polymorphism and acute myocardial infarction in a Spanish population. J. Pineal Res. 2011, 51, 400-404.

118. Li, C.; Shi, Y.; You, L.; Wang, L.; Chen, Z.J. Melatonin receptor 1A gene polymorphism associated with polycystic ovary syndrome. Gynecol. Obstet. Invest. 2011, 72, 130-134.

119. Esposito, T.; Rendina, D.; Aloia, A.; Formicola, D.; Magliocca, S.; de Filippo, G.; Muscariello, R.; Mossetti, G.; Gianfrancesco, F.; Strazzullo, P. The melatonin receptor 1A (MTNR1A) gene is associated with recurrent and idiopathic calcium nephrolithiasis. Nephrol. Dial. Transplant. 2012, 27, 210-218.

120. Li, C.; Shi, Y.; You, L.; Wang, L.; Chen, Z.J. Association of rs10830963 and rs10830962 SNPs in the melatonin receptor (MTNR1B) gene among Han Chinese women with polycystic ovary syndrome. Mol. Hum. Reprod. 2011, 17, 193-198.

121. Ha, E.; Choe, B.K.; Jung, K.H.; Yoon, S.H.; Park, H.J.; Park, H.K.; Yim, S.V.; Chung, J.H.; Bae, H.S.; Nam, M.; et al. Positive relationship between melatonin receptor type 1B polymorphism and rheumatoid factor in rheumatoid arthritis patients in the Korean population. J. Pineal Res. 2005, 39, 201-205.

122. Natarajan, R.; Einarsdottir, E.; Riutta, A.; Hagman, S.; Raunio, M.; Mononen, N.; Lehtimäki, T.; Elovaara, I. Melatonin pathway genes are associated with progressive subtypes and disability status in multiple sclerosis among Finnish patients. J. Neuroimmunol. 2012, 250, 106-110.

123. Qiu, X.S.; Tang, N.L.; Yeung, H.Y.; Lee, K.M.; Hung, V.W.; Ng, B.K.; Ma, S.L.; Kwok, R.H.; Qin, L.; Qiu, Y.; et al. Melatonin receptor 1B (MTNR1B) gene polymorphism is associated with the occurrence of adolescent idiopathic scoliosis. Spine 2007, 32, 1748-1753. 
124. Mórocz, M.; Czibula, A.; Grózer, Z.B.; Szécsényi, A.; Almos, P.Z.; Raskó, I.; Illés, T. Association study of BM.P4, IL6, Leptin, MMP3, and MTNR1B gene promoter polymorphisms and adolescent idiopathic scoliosis. Spine 2011, 36, E123-E130.

125. Hardeland, R. Melatonin in aging and disease-Multiple consequences of reduced secretion, options and limits of treatment. Aging Dis. 2012, 3, 194-225.

126. Dufourny, L.; Levasseur, A.; Migaud, M.; Callebaut, I.; Pontarotti, P.; Malpaux, B.; Monget, P. GPR50 is the mammalian ortholog of Mellc: Evidence of rapid evolution in mammals. BMC Evol. Biol. 2008, 8, 105.

127. Levoye, A.; Dam, J.; Ayoub, M.A.; Guillaume, J.L.; Couturier, C.; Delagrange, P.; Jockers, R. The orphan GPR50 receptor specifically inhibits $\mathrm{MT}_{1}$ melatonin receptor function through heterodimerization. EMBO J. 2006, 25, 3012-3023.

128. Kato, K.; Hirai, K.; Nishiyama, K.; Uchikawa, O.; Fukatsu, K.; Ohkawa, S.; Kawamata, Y.; Hinuma, S.; Miyamoto, M. Neurochemical properties of ramelteon (TAK-375), a selective $\mathrm{MT}_{1} / \mathrm{MT}_{2}$ receptor agonist. Neuropharmacology 2005, 48, 301-310.

129. Sack, R.L.; Lewy, A.J.; Erb, D.L.; Vollmer, W.M.; Singer, C.M. Human melatonin production decreases with age. J. Pineal Res. 1986, 3, 379-388.

130. Karasek, M.; Reiter, R.J. Melatonin and aging. Neuroendocrinol. Lett. 2002, 23, 14-16.

131. Skene, D.J.; Swaab, D.F. Melatonin rhythmicity: Effect of age and Alzheimer's disease. Exp. Gerontol. 2003, 38, 199-206.

132. Cardinali, D.P.; Esquifino, A.I.; Srinivasan, V.; Pandi-Perumal, S.R. Melatonin and the immune system in aging. Neuroimmunomodulation 2008, 15, 272-278.

133. Srinivasan, V.; Pandi-Perumal, S.R.; Maestroni, G.J.M.; Esquifino, A.I.; Hardeland, R.; Cardinali, D.P. Role of melatonin in neurodegenerative diseases. Neurotox. Res. 2005, 7, 293-318.

134. Wu, Y.H.; Fischer, D.F.; Kalsbeek, A.; Garidou-Boof, M.L.; van der Vliet, J.; van Heijningen, C.; Liu, R.Y.; Zhou, J.N.; Swaab, D.F. Pineal clock gene oscillation is disturbed in Alzheimer's disease, due to functional disconnection from the "master clock". FASEB J. 2006, 20, 1874-1876.

135. Wu, Y.H.; Swaab, D.F. Disturbance and strategies for reactivation of the circadian rhythm system in aging and Alzheimer's disease. Sleep Med. 2007, 8, 623-636.

136. Schmid, H.A Decreased melatonin biosynthesis, calcium flux, pineal gland calcification and aging: A hypothetical framework. Gerontology 1993, 39, 189-199.

137. Kunz, D.; Schmitz, S.; Mahlberg, R.; Mohr, A.; Stoter, C.; Wolf, K.J.; Herrmann, W.M. A new concept for melatonin deficit: On pineal calcification and melatonin excretion. Neuropsychopharmacology 1999, 21, 765-772.

138. Skene, D.J.; Vivien-Roels, B.; Sparks, D.L.; Hunsaker, J.C.; Pévet, P.; Ravid, D.; Swaab, D.F. Daily variation in the concentration of melatonin and 5-methoxytryptophol in the human pineal gland: Effect of age and Alzheimer's disease. Brain Res. 1990, 528, 170-174.

139. Uchida, K.; Okamoto, N.; Ohara, K.; Morita, Y. Daily rhythm of serum melatonin in patients with dementia of the degenerate type. Brain Res. 1996, 717, 154-159.

140. Liu, R.Y.; Zhou, J.N.; van Heerikhuize, J.; Hofman, M.A.; Swaab, D.F. Decreased melatonin levels in postmortem cerebrospinal fluid in relation to aging, Alzheimer's disease, and apolipoprotein E-ع4/4 genotype. J. Clin. Endocrinol. Metab. 1999, 84, 323-327. 
141. Mishima, K.; Tozawa, T.; Satoh, K.; Matsumoto, Y.; Hishikawa, Y.; Okawa, M. Melatonin secretion rhythm disorders in patients with senile dementia of Alzheimer's type with disturbed sleep-waking. Biol. Psychiatr. 1999, 45, 417-421.

142. Ohashi, Y.; Okamoto, N.; Uchida, K.; Iyo, M.; Mori, N.; Morita, Y. Daily rhythm of serum melatonin levels and effect of light exposure in patients with dementia of the Alzheimer's type. Biol. Psychiatr. 1999, 45, 1646-1652.

143. Ferrari, E.; Fioravanti, M.; Magri, F.; Solerte, S.B. Variability of interactions between neuroendocrine and immunological functions in physiological aging and dementia of the Alzheimer's type. Ann. N.Y. Acad. Sci. 2000, 917, 582-596.

144. Rosen, R.; Hu, D.N.; Perez, V.; Tai, K.; Yum G.P.; Chen, M.; Tone, P.; McCormick, S.A.; Walsh, J. Urinary 6-sulfatoxymelatonin level in age-related macular degeneration patients. Mol. Vis. 2009, 15, 673-679.

145. Monteleone, P.; Maj, M.; Fusco, M.; Kemali, D.; Reiter, R.J. Depressed nocturnal plasma melatonin levels in drug-free paranoid schizophrenics. Schizophr. Res. 1992, 7, 77-84.

146. Viganò, D.; Lissoni, P.; Rovelli, F.; Roselli, M.G.; Malugani, F.; Gavazzeni, C.; Conti, A.; Maestroni, G. A study of light/dark rhythm of melatonin in relation to cortisol and prolactin secretion in schizophrenia. Neuroendocrinol. Lett. 2001, 22, 137-141.

147. Catapano, F.; Monteleone, P.; Fuschino, A.; Maj, M.; Kemali, D. Melatonin and cortisol secretion in patients with primary obsessive-compulsive disorder. Psychiatr. Res. 1992, 44, $217-225$.

148. Akpinar, Z.; Tokgöz, S.; Gökbel, H.; Okudan, N.; Uğuz, F.; Yilmaz, G. The association of nocturnal serum melatonin levels with major depression in patients with acute multiple sclerosis. Psychiatr. Res. 2008, 161, 253-257.

149. Brugger, P.; Marktl, W.; Herold, M. Impaired nocturnal secretion of melatonin in coronary heart disease. Lancet 1995, 345, 1408.

150. Girotti, L.; Lago, M.; Ianovsky, O.; Carbajales, J.; Elizari, M.V.; Brusco, L.I.; Cardinali, D.P. Low urinary 6-sulphatoxymelatonin levels in patients with coronary artery disease. J. Pineal Res. 2000, 29, 38-42.

151. Sewerynek, E. Melatonin and the cardiovascular system. Neuroendocrinol. Lett. 2002, 23, 79-83.

152. Altun, A.; Yaprak, M.; Aktoz, M.; Vardar, A.; Betul, U.A.; Ozbay, G. Impaired nocturnal synthesis of melatonin in patients with cardiac syndrome X. Neurosci. Lett. 2002, 327, 143-145.

153. Yaprak, M.; Altun, A.; Vardar, A.; Aktoz, M.; Ciftci, S.; Ozbay, G. Decreased nocturnal synthesis of melatonin in patients with coronary artery disease. Int. J. Cardiol. 2003, 89, 103-107.

154. Dominguez-Rodriguez, A.; Abreu-Gonzalez, P.; Garcia-Gonzalez, M.J.; Samimi-Fard, S.; Kaski, J.C.; Reiter. R.J. Light/dark patterns of soluble vascular cell adhesion molecule-1 in relation to melatonin in patients with ST-segment elevation myocardial infarction. J. Pineal Res. 2008, 44, 65-69.

155. Dominguez-Rodriguez, A.; Abreu-Gonzalez, P.; Reiter, R.J. Clinical aspects of melatonin in the acute coronary syndrome. Curr. Vasc. Pharmacol. 2009, 7, 367-373.

156. Rohr, U.D.; Herold, J. Melatonin deficiencies in women. Maturitas 2002, 41, S85-S104. 
157. Claustrat, B.; Loisy, C.; Brun, J.; Beorchia, S.; Arnaud, J.L.; Chazot, G. Nocturnal plasma melatonin levels in migraine: A preliminary report. Headache 1989, 29, 242-245.

158. Claustrat, B.; Brun, J.; Geoffriau, M.; Zaidan, R.; Mallo, C.; Chazot, G. Nocturnal plasma melatonin profile and melatonin kinetics during infusion in status migrainosus. Cephalalgia 1997, 17, 511-517.

159. Bazil, C.W.; Short, D.; Crispin, D.; Zheng, W. Patients with intractable epilepsy have low melatonin, which increases following seizures. Neurology 2000, 55, 1746-1748.

160. Uberos, J.; Augustin-Morales, M.C.; Molina Carballo, A.; Florido, J.; Narbona, E.; Muñoz-Hoyos, A. Normalization of the sleep-wake pattern and melatonin and 6-sulphatoxy-melatonin levels after a therapeutic trial with melatonin in children with severe epilepsy. J. Pineal Res. 2011, 50, 192-196.

161. Aoki, M.; Yokota, Y.; Hayashi, T.; Kuze, B.; Murai, M.; Mizuta, K.; Ito, Y. Disorder of the saliva melatonin circadian rhythm in patients with Meniere's disease. Acta Neurol. Scand. 2006, 113, 256-261.

162. Perras, B.; Kurowski, V.; Dodt, C. Nocturnal melatonin concentration is correlated with illness severity in patients with septic disease. Intensive Care Med. 2006, 32, 624-625.

163. Perras, B.; Meier, M.; Dodt, C. Light and darkness fail to regulate melatonin release in critically ill humans. Intensive Care Med. 2007, 33, 1954-1958.

164. Srinivasan, V.; Pandi-Perumal, S.R.; Spence, D.W.; Kato, H.; Cardinali, D.P. Melatonin in septic shock: Some recent concepts. J. Crit. Care 2010, 25, 656.e1-656.e6.

165. Shigeta, H.; Yasui, A.; Nimura, Y.; Machida, N.; Kageyama, M.; Miura, M.; Menjo, M.; Ikeda, K. Postoperative delirium and melatonin levels in elderly patients. Am. J. Surg. 2001, 182, 449-454.

166. Puy, H.; Deybach, J.C.; Baudry, P.; Callebert, J.; Touitou, Y.; Nordmann, Y. Decreased nocturnal plasma melatonin levels in patients with recurrent acute intermittent porphyria attacks. Life Sci. 1992, 53, 621-627.

167. Bylesjö, I.; Forsgren, L.; Wetterberg, L. Melatonin and epileptic seizures in patients with acute intermittent porphyria. Epileptic Disord. 2000, 2, 203-208.

168. Grin, W.; Grünberger, W. A significant correlation between melatonin deficiency and endometrial cancer. Gynecol. Obstet. Invest. 1998, 45, 62-65.

169. Hu, S.; Shen, G.; Yin, S.; Xu, W.; Hu, B. Melatonin and tryptophan circadian profiles in patients with advanced non-small cell lung cancer. Adv. Ther. 2009, 26, 886-892.

170. O’Brien, I.A.; Lewin, I.G.; O'Hare, J.P.; Arendt, J.; Corrall, R.J. Abnormal circadian rhythm of melatonin in diabetic autonomic neuropathy. Clin. Endocrinol. 1986, 24, 359-364.

171. Peschke, E.; Stumpf, I.; Bazwinsky, I.; Litvak, L.; Dralle, H.; Mühlbauer, E. Melatonin and type 2 diabetes-A possible link? J. Pineal Res. 2007, 42, 350-358.

172. Jan, J.E.; Reiter, R.J.; Wasdell, M.B.; Bax, M. The role of the thalamus in sleep, pineal melatonin production, and circadian rhythm sleep disorders. J. Pineal Res. 2009, 46, 1-7.

173. Hardeland, R. New approaches in the management of insomnia: Weighing the advantages of prolonged release melatonin and synthetic melatoninergic agonists. Neuropsychiatr. Dis. Treat. 2009, 5, 341-354. 
174. Singer, C.; Tractenberg, R.E.; Kaye, J.; Schafer, K.; Gamst, A.; Grundman, M.; Thomas, R.; Thal, L.J. Alzheimer's disease cooperative study. A multicenter, placebo-controlled trial of melatonin for sleep disturbance in Alzheimer's disease. Sleep 2003, 26, 893-901.

175. McCurry, S.M.; Reynolds, C.F.; Ancoli-Israel, S.; Teri, L.; Vitiello, M.V. Treatment of sleep disturbance in Alzheimer's disease. Sleep Med. Rev. 2000, 4, 603-628.

176. Cardinali, D.P.; Brusco, L.I.; Liberczuk, C.; Furio, A.M. The use of melatonin in Alzheimer's disease. Neuroendocrinol. Lett. 2002, 23, 20-23.

177. Srinivasan, V.; Pandi-Perumal, S.R.; Cardinali, D.P.; Poeggeler, B.; Hardeland, R. Melatonin in Alzheimer's disease and other neurodegenerative disorders. Behav. Brain Funct. 2006, 2, 15.

178. Hardeland, R. Melatonin: Signaling mechanisms of a pleiotropic agent. BioFactors 2009, 35, 183-192.

179. Dubocovich, M.L.; Markowska, M. Functional $\mathrm{MT}_{1}$ and $\mathrm{MT}_{2}$ melatonin receptors in mammals. Endocrine 2005, 27, 101-110.

180. Ebisawa, T.; Kajimura, N.; Uchiyama, M.; Katoh, M.; Sekimoto, M.; Watanabe, T.; Ozeki, Y.; Ikeda, M.; Jodoi, T.; Sugishita, M.; et al. Alleic variants of human melatonin 1a receptor: Function and prevalence in subjects with circadian rhythm sleep disorders. Biochem. Biophys. Res. Commun. 1999, 262, 832-837.

181. Bonnefond, A.; Clément, N.; Fawcett, K.; Yengo, L.; Vaillant, E.; Guillaume, J.L.; Dechaume, A.; Payne, F.; Roussel, R.; Czernichow, S.; et al. Rare MTNR1B variants impairing melatonin receptor 1B function contribute to type 2 diabetes. Nat. Genet. 2012, 44, 297-301.

182. Nagorny, C.; Lyssenko, V. Tired of diabetes genetics? Circadian rhythms and diabetes: The MTNR1B story? Curr. Diab. Rep. 2012, 12, 667-672.

183. Claustrat, B.; Brun, J.; Chazot, G. The basic physiology and pathophysiology of melatonin. Sleep Med. Rev. 2005, 9, 11-24.

184. Hardeland, R.; Poeggeler, B.; Srinivasan, V.; Trakht, I.; Pandi-Perumal, S.R.; Cardinali, D.P. Melatonergic drugs in clinical practice. Arzneimittelforschung 2008, 58, 1-10.

185. Srinivasan, V.; Pandi-Perumal, S.R.; Trahkt, I.; Spence, D.W.; Poeggeler, B.; Hardeland, R.; Cardinali, D.P. Melatonin and melatonergic drugs on sleep: Possible mechanisms of action. Int. J. Neurosci. 2009, 119, 821-846.

186. Hardeland, R. Neurobiology, pathophysiology, and treatment of melatonin deficiency and dysfunction. Scientific WorldJournal 2012, 2012, 640389.

187. Hardeland, R.; Poeggeler, B. Melatonin and synthetic melatonergic agonists: Actions and metabolism in the central nervous system. Cent. Nerv. Syst. Agents Med. Chem. 2012, 12, 189-216.

188. Mulchahey, J.J.; Goldwater, D.R.; Zemlan, F.P. A single blind, placebo controlled, across groups dose escalation study of the safety, tolerability, pharmacokinetics and pharmacodynamics of the melatonin analog $\beta$-methyl-6-chloromelatonin. Life Sci. 2004, 75, 1843-1856.

189. Bourin, M.; Mocaër, E.; Porsolt, R. Antidepressant-like activity of S 20098 (agomelatine) in the forced swimming test in rodents: Involvement of melatonin and serotonin receptors. J. Psychiatr. Neurosci. 2004, 29, 126-133.

190. Karim, A.; Tolbert, D.; Cao, C. Disposition kinetics and tolerance of escalating single doses of ramelteon, a high affinity MT1 and MT2 melatonin receptor agonist indicated for the treatment of insomnia. J. Clin. Pharmacol. 2006, 46, 140-148. 
191. Pandi-Perumal, S.R.; Srinivasan, V.; Poeggeler, B.; Hardeland, R.; Cardinali, D.P. Drug insight: The use of melatonergic agonists for the treatment of insomnia-Focus on ramelteon. Nat. Clin. Pract. Neurol. 2007, 3, 221-228.

192. Rivara, S.; Mor, M.; Bedini, A.; Spadoni, G.; Tarzia, G. Melatonin receptor agonists: SAR and applications to the treatment of sleep-wake disorders. Curr. Top. Med. Chem. 2008, 8, 954-968.

193. Hardeland, R. Investigational melatonin receptor agonists. Expert Opin. Investig. Drugs 2010, $19,747-764$.

(C) 2013 by the authors; licensee MDPI, Basel, Switzerland. This article is an open access article distributed under the terms and conditions of the Creative Commons Attribution license (http://creativecommons.org/licenses/by/3.0/). 